\title{
From the retired
}

\section{0 years in neurology, a retrospect}

\section{Lord Walton of Detchant}

Former Professor of Neurology, University of Newcastle upon Tyne; Former Warden, Green College, Oxford; Former President, World Federation of Neurology

\author{
Practical Neurology, 3, 52-55
}

I had not come across Practical N eurology until I received a recent issue from the Editor. $\mathrm{H}$ aving now seen it, I am impressed by its content and format and was particularly interested to read two of the articles. The first on myositis reminded me of my second monograph, published with Raymond Adamsin 1956, which was on the topic of polymyositis. I also enjoyed the article by Julian Fearnly on superficial siderosis of the nervous system, because Bernard Tomlinson and I published a comprehensive review of the topic and reported a case resulting from an ependymoma of the lateral ventricle back in 1964. Reading these articles and others giving practical advice to practising neurologists led me to reflect, now that I am 80 years of age, on my early yearsin neurology and on somelessons I have learned during a lengthy career in teaching, research and clinical practice.

When I became house physician to the late Professor FJ Nattrass (author of a popular textbook called The Commoner N ervousD iseases) at theRoyal Victorialnfirmary (RVI) in Newcastle in 1946, I well remember that if a patient was then diagnosed as suffering from tuberculous meningitis, he or she was immediately transferred to a sideroom under heavy sedation because no-one with that disease had ever been known to recover. And I was concerned that the chief would not allow any patient diagnosed as suffering from disseminated sclerosis (not then 'multiple') to have a lumbar puncture, because there was a widespread belief that this caused clinical deterioration. Goodness knows how many patients with spinal cord compression due to tumours or spondylosis must have been missed, because cervical spondylotic myelopathy had not then been characterized and myelography was rarely, if ever, performed. Goodness knows, too, how many patients were damaged by radiotherapy to the cervical cord, at the time a popular treatment for syringomyelia. The oft-quoted statement that neurology was then almost entirely a diagnostic and not a therapeutic speciality did have some justification. But clinical diagnosis was not invariably accurate, often, indeed, being speculative, as even air encephalography or other contrast studies, could only be carried out by transfer to a neurosurgical ward.

After military service and on becoming a medical registrar in N ewcastle, I began a survey of cases of subarachnoid haemorrhage, publishing my MD thesis and subsequently a monograph. Before then, under the influence of the great Sir James Spence, whose houseman I also was, I leaned towards a career in paediatrics, but during my medical registrarship I worked with the legendary Henry M iller of the black jacket, grey waistcoat, pin-striped trousers and carna- 
tion in thebutton-hole. Atthat timehewasmaking his way as an assistant physician at the RVI, and in private practice, and was locally known as $\mathrm{H}$ enry Gorgeous M iller. D uring his service in the Royal Air Force as a neuropsychiatrist, he had acquired a diploma in psychological medicine, which hesubsequently suppressed because he often offended psychiatrists by referring to their discipline as 'neurology without physical signs'. When asked if he practised psychiatry, he replied 'only in private practice'!

As my two-year registrarship drew to a close, I was invited by Professor Nattrass to assist him in some research into muscular dystrophy and other neuromuscular diseases, and so had to learn electromyography, which I did at St. Thomas's Hospital in London with Dr Philippe Bauwens and at the National Hospital, Queen Square with Bill Cobb. I also did theEEG course and found myself, on returning to Newcastle, being required to interpret all the EEGs (then recorded in the Department of Psychological Medicine, headed by Alexander Kennedy). But as I embarked on a comprehensive study of the clinical manifestations and genetics of muscular dystrophy in the north of England, I soon recognized that clinical history-taking and examination, and the EM G, were not enough. And so, with a Nuffield Foundation Travelling Fellowship, I spent ayear with Raymond Adams at the M assachusetts General Hospital in Boston wherel learned muscle pathology. But even that fine neurologist and teacher, and master of clinicopathological correlation, did - rarely - fall into error, asindeed weall do. In particular, I remember him diagnosing a patient who was clearly suffering from muscular dystrophy as a case of polymyositis because the muscle biopsy demonstrated striking areas of focal necrosis of muscle, which heaverred did not occur in muscular dystrophy. Someyears later, herecognized that such changes are indeed common in that condition.

After a fruitful year with Carmichael in the Neurological Research Unit at Queen Square, wherel wasstunned bytheclinical expertiseand diagnostic brilliance of people like Sir Charles Symonds, I returned to the RVI in Newcastle. I became first assistant to Henry M iller, who by then had been confirmed as the first consultant neurologist in Newcastle, and in 1958 । myself became the first consultant neurologist

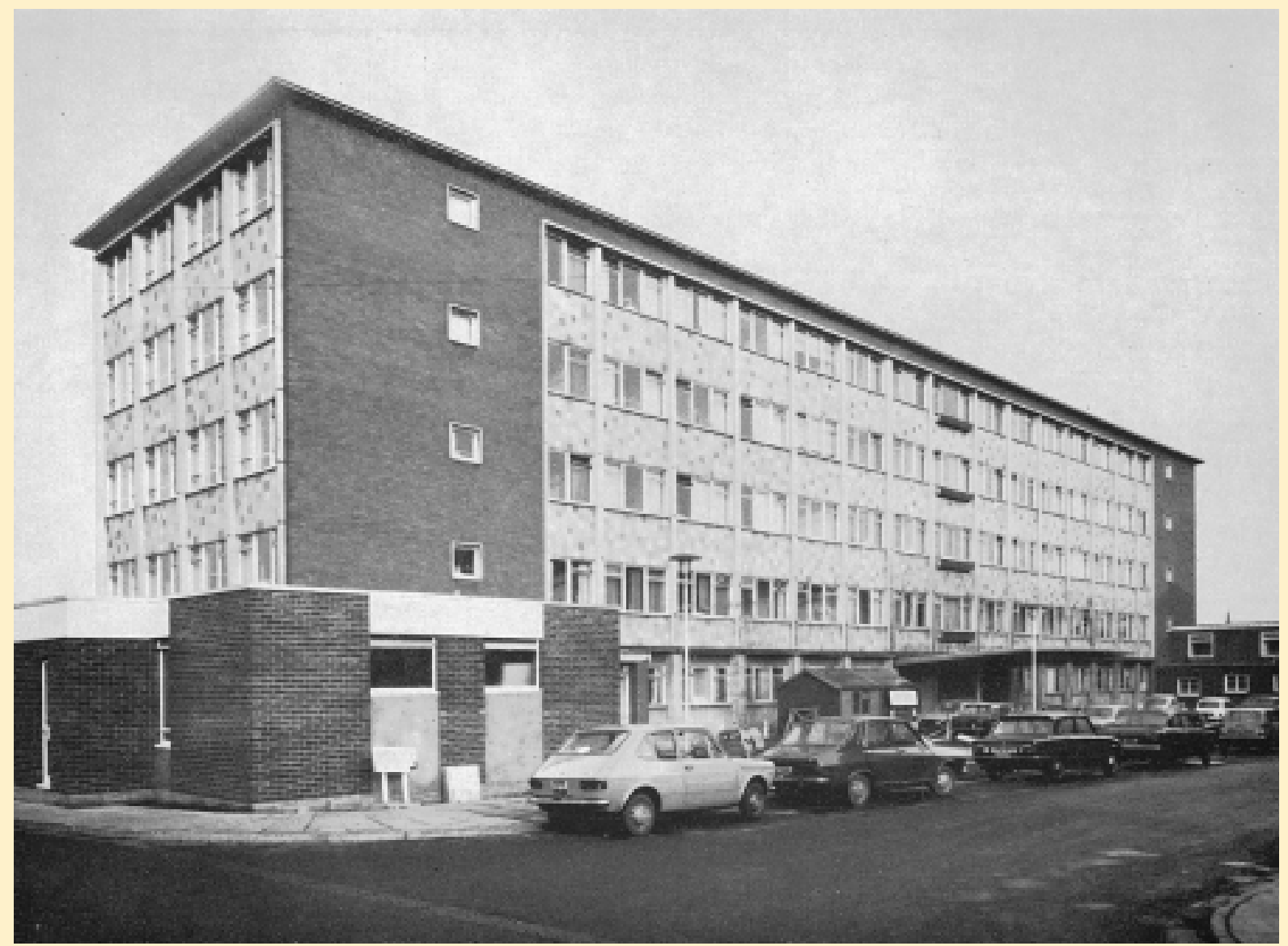

The regional Neurological Centre at the Newcastle General Hospital when it opened in 1962. 
to the N orthern Region, based at the Newcastle General Hospital. The appointment involved a weekly 'open' out-patient session for general practitioner referrals at the General Hospital, a weekly 'closed' clinic at the RVI for consultant referrals only, and two other 'closed' clinics held fortnightly at Durham 20 miles away, and at M iddlesbrough, 45 miles away. As it wasthen expected that one would carry out domiciliary consultations with general practitioners, which were very popular in the 1960s, I was regularly travelling 20000 miles a year and seeing upwards of 40-45 new patients every week. I remember especially being asked by the late Dr Waldie of Great Ayton in North Yorkshire to see a patient with him; the round trip of 120 miles was worth it as the patient proved to have acute intermittent porphyria. In those days the general practitioner invariablyattended in what was a genuine domiciliary consultation. But exhaustion occasionally supervened when, for example, on oneM onday I saw 12 new patients in my morning clinic at the Newcastle General Hospital and then ate a sandwich in the car on my way to Middlesbrough where I saw eight new patients referred by consultants followed by another four ward consultations in Middllesbrough and Stockton. Returning home at $9.45 \mathrm{pm}$, I was met by my wife who said 'D on't put thecar away, there's a domiciliary in Birtley' - a patient who proved to have had an anterior spinal artery thrombosis. And for 10 years, until I received a personal chair, I also saw private patients at my home on two afternoons and evenings every week.

On appointment as a consultant I was allowed four beds on GF Rowbothams's ward at the General Hospital to which I could admit patients requiring air studies, angiography and the like, but I also had 14 beds at Chester-leStreet General H ospital, 12 miles away, to which patients could be transferred for on-going care and rehabilitation. And I shared the services of a secretary with three other consultants. Plainly
Sir Richard (as he then was) Attenborough, President of the Muscular Dystophy Group, with Mrs (later dame) Catherine Cookson who were involved in fund raising for our Muscular Dystophy laboratories in the 1960 s.

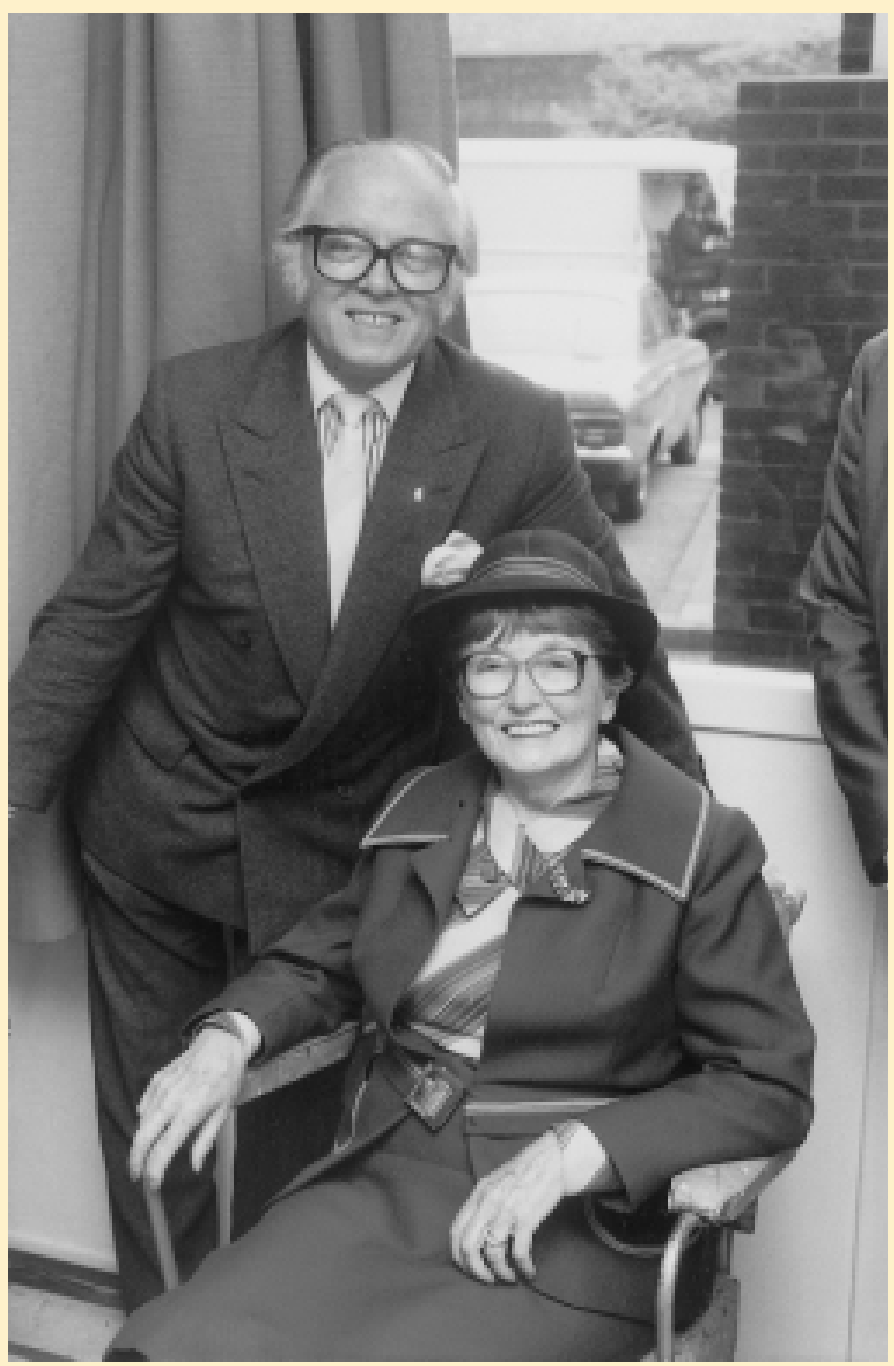


this clinical load was, even by the standards of yester-year, excessive but the experience was invaluable.

I managed to obtain some research facilities under grants from various muscular dystrophy organizations to employ research assistants in clinical neurophsyiology, biochemistry and neuropathology. And, above all, at last I had, in Rosemary Allan, full-time secretarial help paid for on a grant. Research opportunities escalated when the Regional Neurological Centreopened in 1962 at the General H ospital, and Jack Foster joined meas a consultant and took over some of my regional responsibilities. For the first time we then had a dedicated neurology ward of 32 beds, with greatly improved investigational and research opportunities. Eventually, with private money, we built the Muscular Dystrophy Research Laboratories adjacent to the Regional Centre, and ultimately attracted grants from the Muscular Dystrophy Associations of America and Canada, the M uscular Dystrophy Group of Great Britain, theM edical Research Council and theWellcomeTrust.

Even in the 1960s and 1970s, few of us foresaw the huge developments that were to occur in neurology in the succeeding decades. The virtual conquest of bacterial infection, the vast improvements in diagnosis achieved with computerized tomography, nuclear magnetic resonance, Doppler imaging, and so many more, have transformed clinical practice with immense benefit to patients and neurologists alike. Burgeoning developments in molecular biology, including the prospect of stem-cell therapy and gene transfer, have brought new hope to many patients suffering from neurological disorders. But in the UK we even now havefar too few neurologists, carrying much too heavy a clinical load; thus, most patients with stroke are still cared for by general physicians and geriatricians. Hence it is rarely feasible to follow the example of the cardiologists by admitting patients with strokes to hospital rapidly, carrying out brain imaging at once to identify infarcts as distinct from haemorrhage, and to givethrombolytics within 3 hours. Onecan but hopethat the expansion in consultant numbers and in facilities now envisaged by the current UK government will prove possible.

To have witnessed these and so many other major developments has been, for me, a period of great excitement. Were I starting again, I am sure I would have wished to spend a period of intensive study of a basic scientific discipline such as molecular biology in order to inform my research methods and clinical practice, and it is good to see that many young people in neurology are following that road. But I must express someconcern over what I seeasthepossibleerosion of clinical skills resulting from thescientific revolution. Years ago, as a visiting professor in Miami, I was examining a patient who had pins and needles in the ring and little fingers of her right hand and wasting of all the small muscles. She had been subjected to no fewer than three cervical laminectomies because of modest bulges of her intervertebral discs demonstrated by myelography. But when I questioned the senior resident asto whether such clinical features were a common consequence of cervical myel opathy, shesaid 'Geedoc, it's no good asking me; I didn't do upper limb in anatomy'. I then suggested the possibility of a cervical rib, but was told that no such lesion was shown on X-ray. H owever, when I rolled thecords of thebrachial plexusunder my fingers above the clavicle, this reproduced her symptoms. Subsequent surgical division of a fibrous band attached to thefirstrib (thesurgeons took some persuading), which was compressing the inner cord of the plexus, relieved her symptoms. Much more recently, I was asked to see a patient who was about to undergo magnetic resonancespectroscopy to study themetabolism of hisskeletal muscles. H ehad been diagnosed as a case of Becker muscular dystrophy in view of the widespread hypertrophy of skeletal muscles that caused pain and aching on exertion and marked slowness of gait. By the timel saw him, he had already undergone electromyography and a muscle biopsy (the latter had proved negative and the EMG was equivocal). The senior resident in the unit had been trained in endocrinology, and it was plain that the patient had not been fully examined. All hisreflexeswere exceptionally slow, hehad a deep voice, uniform enlargement of the thyroid and other features clearly demonstrating that he was suffering, at theageof 17, from H offmann's syndromedueto hypothyroidism. I mention these two cases, not in any attempt to publicise my diagnostic acumen, sincelikeall clinical neurologists I can well remember many painful errors of my own, but simply to stressmy view that theskills of clinical history-taking and examination and assessment of the whole patient, and not solely of thenervous system, remain the cornerstones of clinical neurology and practice. This theme will, I am sure, continue to be the objective of the articles to be published in Practical N eurology. 